\title{
Erratum to: Electrogenic capacity and community composition of anodic biofilms in soil-based bioelectrochemical systems
}

\author{
D. B. Ringelberg • K. L. Foley • C. M. Reynolds
}

Published online: 29 February 2012

(C) Springer-Verlag 2012

Erratum to: Appl Microbiol Biotechnol

DOI 10.1007/s00253-011-3264-9

The currents reported for the simple bioelectrochemical soil cells were incorrect. Instead of producing maximum sustained currents of 1.5-2.1 mA, the cells produced 1.5$2.1 \mu \mathrm{A}$ of current. As a result, the output is not comparable to that reported by either Ringeisen et al. (2006) or Mohan et al. (2008), instead being less.

\footnotetext{
The online version of the original article can be found at http://dx.doi. org/10.1007/s00253-011-3264-9.

D. B. Ringelberg $\cdot$ K. L. Foley $\cdot$ C. M. Reynolds

US Army Cold Regions Research and Engineering Center,

Hanover, NH, USA

D. B. Ringelberg $(\square)$

US Army ERDC-CRREL,

72 Lyme Rd,

Hanover, NH 03755, USA

e-mail: david.b.ringelberg@usace.army.mil
} 